\title{
Human Coronavirus NL63 Among Other Respiratory Viruses in Clinical Specimens of Egyptian Children and Raw Sewage Samples
}

\author{
Waled Morsy El-Senousy ${ }^{1}$ (D) . Mohamed Shouman ${ }^{2}$
}

Received: 11 January 2021 / Accepted: 29 May 2021 / Published online: 4 June 2021

(c) The Author(s), under exclusive licence to Springer Science+Business Media, LLC, part of Springer Nature 2021

\begin{abstract}
The objective of this study was to investigate human coronavirus NL63 (HCoV-NL63) prevalence among the other respiratory viruses such as parainfluenza, respiratory syncytial virus, and non-enteric adenoviruses in clinical specimens of Egyptian children and raw sewage samples. One hundred clinical specimens were collected from Egyptian children suffering from upper and lower respiratory viral infections in the years 2005-2006 to detect HCoV-NL63 genome using RT-PCR. All the specimens were negative for the virus. Also, a complete absence of HCoV-NL63 genome was observed in the twenty-four raw sewage samples collected from two wastewater treatment plants within Greater Cairo from February 2006 to January 2007. Using nested RT-PCR, parainfluenza virus type 1, respiratory syncytial virus type A, adenovirus type 4, and adenovirus type 7 were detected in $3 \%, 2 \%, 5 \%$, and $2 \%$ of the clinical specimens, respectively. Of these viruses, only adenovirus type 4 was detected in $1 / 24(4.17 \%)$ of the raw sewage samples, while a complete absence of the other investigated respiratory viruses was observed in the raw sewage samples. The low percentage of positivity in the clinical specimens, the concentration method of the raw sewage samples, and the indirect routes of transmission may be the reasons for the absence of respiratory viruses in raw sewage samples. On the other hand, enteric adenoviruses were detected in 21/24 (87.5\%) of the raw sewage samples with a higher prevalence of adenovirus type 41 than adenovirus type 40 . A direct route of transmission of enteric viruses to raw sewage may be the reason for the high positivity percentage of enteric adenoviruses in raw sewage samples.
\end{abstract}

Keywords Human coronavirus NL63 - Non-enteric adenoviruses · Parainfluenza virus · Respiratory syncytial virus · Clinical specimens $\cdot$ Raw sewage

\section{Introduction}

Respiratory RNA viruses are associated with increased morbidity and mortality among high-risk populations including the elderly, immunocompromised individuals, pre-term infants, and neonates (Auburn et al., 2011).

Coronavirus infections of humans are mostly restricted to the respiratory tract. The human coronaviruses were first identified in the mid-1960s (HCoV-229E and HCoV-OC43)

Waled Morsy El-Senousy

waledmorsy@hotmail.com

1 Environmental Virology Lab, Water Pollution Research Department, Environmental Research Division and Food-Borne Viruses Group, Centre of Excellence for Advanced Sciences, National Research Centre (NRC), 33 El-Buhouth st., Dokki, Giza 12622, Egypt

2 Pediatric Department, Centre of Medical Excellence, Medical Research Division, NRC, Dokki, Giza, Egypt
(Tyrrell \& Bynoe, 1965; Hamre \& Procknow, 1966; McIntosh et al., 1967), but in 2003, 2004, and 2005, three new human coronavirus species have been identified (SARSCoV, HCoV-NL63 and HCoV-HKU1, respectively (Ksiazek et al., 2003; Drosten et al., 2003; van der Hoek et al., 2004; Woo et al., 2005). Two study teams happened to identify the novel virus in 2004 (Fouchier et al., 2004; van der Hoek et al., 2004). However, Arden et al. (2005), as well as Esper et al. (2005), reported detection of NL63 from specimens obtained in 2001 and 2002, respectively. It soon turned out that HCoV-NL63 infection occurs frequently in children (Dijkman et al., 2008; Shao et al., 2007; van der Hoek et al., 2005), is observed around the globe (van der Hoek, 2007), and infection is associated with croup and acute otitis media (Talbot et al., 2009; van der Hoek, 2007; van der Hoek et al., 2005). The complete genome sequence indicated that this virus is not recombinant, but rather a new group 1 coronavirus. The in vitro host cell range of HCoV-NL63 was notable because it replicates on tertiary monkey kidney cells and 
the monkey kidney LLC-MK2 cell line. The viral genome contains distinctive features, including a unique $\mathrm{N}$-terminal fragment within the spike protein (van der Hoek et al., 2004).

Coronaviruses, a genus of the Coronaviridae family, are enveloped viruses with a large plus-strand RNA genome. The genomic RNA is $27-32 \mathrm{~kb}$ in size, capped, and polyadenylated. Three serologically distinct groups of coronaviruses have been described. Within each group, viruses are characterized by their host range and genome sequence. Coronaviruses have been identified in mice, rats, chickens, turkeys, swine, dogs, cats, rabbits, horses, cattle and humans, and can cause a variety of severe diseases including gastroenteritis and respiratory tract diseases. $\mathrm{HCoV}-229 \mathrm{E}$ and $\mathrm{HCoV}-\mathrm{OC} 43$ are known to cause the common cold. The SARS-CoV causes life-threatening pneumonia (van der Hoek et al., 2004).

A significant number of the many RT-PCR assays described are for respiratory viruses. These pathogens cause a considerable burden of illness, particularly during the winter. Since different viruses often cause similar symptoms, appropriate patient management can be assisted by rapid laboratory tests with a low limit of detection. Respiratory viruses had traditionally been detected by cell culture and also by commercially available direct immunofluorescence tests. RT-PCR is faster and more sensitive than cell culture and offers greater sensitivity than immunofluorescence (Dingle et al., 2004).

Our first objective in this study was to investigate mainly HCoV-NL63 in Egyptian children and also other respiratory viruses which cause conjunctivitis, upper respiratory catarrh, and bronchiolitis in the same samples. Our second objective is to estimate the role of raw sewage in expressing the most frequent types of respiratory viruses in the Egyptian community.

\section{Materials and Methods}

\section{Clinical Specimens}

One hundred clinical specimens were collected from children of age ranging from 1 to 60 months from a pediatric private clinic in Greater Cairo. The time of the collection of specimens was from November 2005 to April 2006. The children suffered from fever, runny nose, pharyngitis, wheezy chest, and pneumonia. Specimens were obtained from the upper and lower respiratory system using sterile disposable swabs.

\section{Raw Sewage Samples}

Twenty-four raw sewage samples were collected from two different wastewater treatment plants (WWTPs) within Greater Cairo (El-Gabal El-Asfar and Zenin). Samples were collected monthly for 12 months from February 2006 to January 2007.

\section{Preparation of Clinical Specimens}

Viruses were eluted from swabs using sterile deionized water. Swabs were immersed in $1 \mathrm{ml}$ of deionized water in an Eppendorf with continuous movement of swabs for $2 \mathrm{~min}$. Squeezing of swabs was performed to confirm the viral release.

\section{Concentration of Raw Sewage Samples}

Sewage samples were concentrated by filtration through negatively charged nitrocellulose membranes (ALBET-Spain, 0.45 - $\mu \mathrm{m}$-pore size, and 142-mm-diameter filter series) after the addition of $\mathrm{AlCl}_{3}$ to a final concentration of $0.5 \mathrm{mM}$ and acidification to $\mathrm{pH} 3.5$ and finally passing through Whatman No. 1 filter paper. The viruses adsorbed to the membrane were eluted with $75 \mathrm{ml}$ of $0.05 \mathrm{M}$ glycine buffer, $\mathrm{pH} 9.5$ (using $\mathrm{HCl} 5 \mathrm{~N}$ ), containing 3\% beef extract (Lab-Lemco powder, OXOID, UK) (Rose et al., 1984; Smith \& Gerba, 1982). Eluted viruses were re-concentrated using the organic flocculation method (Katzenelson et al., 1976). Samples were neutralized and kept at $-80{ }^{\circ} \mathrm{C}$ until use.

\section{Viral RNA Extraction}

Viral RNA was extracted from $100 \mu$ of the supernatant by BIOZOL Total RNA Extraction reagent (BioFlux, Japan) according to the manufacturer's instructions.

\section{Viral DNA Extraction}

It was done using a viral DNA extraction kit (Qiagen) and according to the manufacturer's instructions.

\section{Nested RT-PCR for Detection of HCoV-NL63 in Clinical Specimens and Raw Sewage Samples}

It was performed according to Van der Hoek et al. (2004). Briefly, the diagnostic assay was designed based on the sequence of the $1 \mathrm{~b}$ gene. The reverse transcription was performed with M-MLV reverse transcriptase enzyme (Promega-USA), using $10 \mathrm{ng}$ of reverse transcription primer (repSZ-RT, 5'-CCACTATAAC-3'; coordinate 16232 in 
HCoV-NL63). The entire reverse transcription mixture was added to the first PCR mixture containing $100 \mathrm{ng}$ of primer repSZ-1 (5'-GTGATGCATATGCTAATTTG-3'; coordinate 15973 ) and $100 \mathrm{ng}$ of primer repSZ-3 (5'-CTCTTGCAG GTATAATCCTA-3'; coordinate 16210). The PCR reaction consisted of the following steps: $95^{\circ} \mathrm{C}$ for $5 \mathrm{~min}$; then 35 cycles of $95{ }^{\circ} \mathrm{C}$ for $1 \mathrm{~min}, 55^{\circ} \mathrm{C}$ for $1 \mathrm{~min}$, and $72{ }^{\circ} \mathrm{C}$ for $2 \mathrm{~min}$; then $72^{\circ} \mathrm{C}$ for $10 \mathrm{~min}$.

A nested PCR was started using $5 \mu \mathrm{l}$ of the first PCR product with $100 \mathrm{ng}$ of primer repSZ-2 (5'-TTGGTAAAC AAAAGATAACT-3'; coordinate 16012) and $100 \mathrm{ng}$ of primer repSZ-4 (5'-TCAATGCTATAAACAGTCAT-3'; coordinate 16181). Twenty-five PCR cycles were performed using the same profile as the first PCR. Ten microliters of each PCR product were analyzed by electrophoresis on $3 \%$ agarose gels (Panreac-Spain). Positive control (HCoVNL63) was used which was kindly provided by Prof. Dr. Luis Enjuanes, Department of Molecular and Cell Biology, National Center of Biotechnology (CNB-CSIC), Campus Universidad Autónoma de Madrid, Madrid, Spain.

\section{Nested monoplex RT-PCR for Detection of Parainfluenza Viruses and Respiratory Syncytial Viruses in Clinical Specimens and Raw Sewage Samples}

It was performed according to Dingle et al. (2004) to detect parainfluenza viruses type 1,2 , and 3 and respiratory syncytial viruses type A and B.

\section{Detection of Adenoviruses Using Nested PCR}

It was done according to Puig et al. (1994) using the specific primers hex AA 1885, hex AA 1913 for the first round PCR, and nehex AA 1893 and nehex AA 1905 for the second round PCR for detection of human adenovirus and were selected from the DNA sequence of the open reading frame of hexon gene. PCR products $(10 \mu \mathrm{l})$ were analyzed by electrophoresis on 3\% agarose gels (Panreac-Spain).

\section{Sequencing of Adenovirus Positive Samples}

The PCR products of positive samples of adenoviruses were sequenced. Fifty to one hundred $\mu$ l of the PCR products were purified using a high pure PCR products purification kit (Qiagen) following the manufacturer's instructions. Sequencing was performed on 1-7 $\mu \mathrm{l}$ of the purified products with an $\mathrm{ABI}$ prism Big dye termination cycle sequencing ready reaction kit (Applied Biosystem) using the same primers as in the PCR and following the manufacturer's instructions. The DNA was sequenced with an ABI prism 310 automated DNA sequencer. Sequence data from both strands of the PCR products were aligned and compared using the CLUSTALW and BLAST programs (European Bioinformatics Institute).

\section{Results}

\section{Frequency of Respiratory Viruses in Egyptian Children}

In the one hundred investigated clinical specimens of Egyptian children, the prevalence of the examined respiratory viruses were 0/100 (0\%) for HCoV-NL63, 3/100 (3\%) for parainfluenza virus type $1,0 / 100(0 \%)$ for both parainfluenza virus types 2 and 3,2/100 (2\%) for respiratory syncytial virus type $\mathrm{A}$, and $0 / 100(0 \%)$ for respiratory syncytial virus type B, 7/100 (7\%) for adenoviruses (Table 1). No mixed viruses were observed in the specimens.

\section{Frequency of Viruses in Raw Sewage Samples}

Adenoviruses were detected in 22/24 (91.67\%) of the raw sewage samples. On the other hand, a complete absence of all the other studied viruses in all the twenty-four investigated raw sewage samples was observed (Table 1).

\section{Sequence Analysis of Adenovirus Positive Samples}

Sequence analysis of the PCR products of the seven positive clinical specimens for adenoviruses indicated five samples had similar sequences and with $96.81 \%$ similarity with human adenovirus type 4 isolate BA_506-2009 hexon gene, while two samples had similar sequences and with $94.62 \%$ similarity with human adenovirus type 7 isolate $\mathrm{HAdV} /$ $\mathrm{WH} / 46 / 2019$ hexon gene. PCR products of the twenty-two positive raw sewage samples for adenoviruses indicated seventeen samples had similar sequences and with $93.18 \%$ similarity with human adenovirus type 41 mastadenovirus $\mathrm{F}$

Table 1 Frequency of respiratory viruses in clinical specimens and raw sewage samples

\begin{tabular}{lll}
\hline Virus & $\begin{array}{l}\text { Frequency in } \\
\text { clinical speci- } \\
\text { mens }\end{array}$ & $\begin{array}{l}\text { Frequency in raw } \\
\text { sewage samples }\end{array}$ \\
\hline HCoV-NL63 & $0 / 100(0 \%)$ & $0 / 24(0 \%)$ \\
Parainfluenza virus type 1 & $3 / 100(3 \%)$ & $0 / 24(0 \%)$ \\
Parainfluenza virus type 2 & $0 / 100(0 \%)$ & $0 / 24(0 \%)$ \\
Parainfluenza virus type 3 & $0 / 100(0 \%)$ & $0 / 24(0 \%)$ \\
$\begin{array}{l}\text { Respiratory syncytial virus } \\
\text { type A }\end{array}$ & $2 / 100(2 \%)$ & $0 / 24(0 \%)$ \\
$\begin{array}{l}\text { Respiratory syncytial virus } \\
\text { type B }\end{array}$ & $0 / 100(0 \%)$ & $0 / 24(0 \%)$ \\
Adenoviruses & $7 / 100(7 \%)$ & $22 / 24(91.67 \%)$ \\
\hline
\end{tabular}


strain SA6749, four samples had similar sequences and with 95.56\% similarity with human adenovirus type 40 mastadenovirus F isolate Human/China/Shanghai/FX3-1613263/ F40, and one sample had $96.81 \%$ similarity with human adenovirus type 4 isolate BA_506-2009 hexon gene and 100\% similarity to the adenovirus type 4 strains investigated in the five clinical specimens Table 2.

\section{Discussion}

In this study, our first objective was to investigate HCoVNL63 in Egyptian clinical specimens and sewage samples. We failed to detect HCoV-NL63 genome in any of the one hundred clinical specimens and the twenty-four raw sewage samples, although some reports in more than one country reported the detection of the HCoV-NL63 in clinical specimens. HCoV-NL63 infection is found worldwide but is rarely positive by RT-PCR assays (Arden et al., 2005; Chiu et al., 2005; Esper et al., 2005; Suzuki et al., 2005). The positive rate of HCoV-NL63 infection in children ranged from $1.2 \%$ in Japan (Suzuki et al., 2005), 1.3\% in Taiwan (Wu et al., 2008), 2.1\% in Australia (Arden et al., 2005), 2.3\% in Belgium (Moes et al., 2005), 2.5\% in Canada (Bastien et al., 2005), 7\% in Switzerland (Kaiser et al., 2005), to 9.3\% in children and adolescents in France (Vabret et al., 2005). The low prevalence in all these studies may explain the complete absence of HCoV-NL63 in our specimens. Additionally, HCoV-NL63 infection is predominant in the winter season in Australia, Belgium, Canada, France, Germany, and Japan (Arden et al., 2005; Bastien et al., 2005; Esper et al., 2005; Moes et al., 2005; Vabret et al., 2005; van der Hoek et al., 2005), but in spring and summer in Hong Kong (Chiu et al., 2005) and autumn and winter in Taiwan (Wu et al., 2005). van der Hoek et al. (2010) reported that the winter season is the preferred season for infection by HCoV-NL63, yet large year-to-year differences in frequency are apparent (above $10 \%)$. This indicates that there is an inter-epidemic period, but it cannot be determined whether HCoV-NL63 peaks

Table 2 Frequency of enteric and non-enteric adenoviruses in the clinical specimens and raw sewage samples based on the results of the sequencing

\begin{tabular}{lll}
\hline Adenovirus types & Clinical specimens & Raw sewage samples \\
\hline $\begin{array}{l}\text { Enteric adenovirus type } \\
40\end{array}$ & $0 / 100(0 \%)$ & $4 / 24(16.7 \%)$ \\
$\begin{array}{l}\text { Enteric adenovirus type } \\
\quad 41\end{array}$ & $0 / 100(0 \%)$ & $17 / 24(70.83 \%)$ \\
$\begin{array}{l}\text { Non-enteric adenovirus } \\
\text { type } 4\end{array}$ & $5 / 100(5 \%)$ & $1 / 24(4.17 \%)$ \\
$\begin{array}{l}\text { Non-enteric adenovirus } \\
\text { type } 7\end{array}$ & $2 / 100(2 \%)$ & $0 / 24(0 \%)$ \\
\hline
\end{tabular}

every 2, 3, or more years. This periodicity of infection of HCoV-NL63 may also explain the absence of the virus in our clinical specimens and environmental samples. The peak of HCoV-NL63 may have a chance of positivity if the collection of samples was done at another time. On the other hand, the virus could be detected in clinical specimens or sewage samples if they were collected in another geographical area in Egypt, although, the area of collection (Greater Cairo) represents the highest population density throughout all Egyptian towns. So, these results do not confirm the absence of this virus in the Egyptian community. Sufficient detection of infectious viral particles in the environment is affected by several obstacles such as virus size, the large variability among and within viral genera, the low concentration, the presence of substances that can interfere with analysis procedures, the limits of detection of proposed techniques, and absence of reliable controls (Vasickova et al., 2010). Non-enveloped viruses can survive for extended periods on surfaces, while enveloped viruses, including HCoV-NL63, remain infectious on surfaces after several days. The persistence of dried viruses is affected by various environmental conditions and factors such as heat, moisture, $\mathrm{pH}$, and the type of surface. Furthermore, the compositions of media may also influence the persistence of viruses (Firquet, 2015). Methods for recovering enveloped viruses such as $\mathrm{HCoV}$ NL63 from wastewater according to adsorption to the solid fraction which is different from non-enveloped viruses may be another factor that affects the percentage of positivity (Ye et al., 2016). Our viral concentration method may not efficient enough to concentrate HCoV-NL63 from sewage. Recent studies which detected the new human coronavirus strain (SARS-CoV-2) used other concentration methods such as aluminum hydroxide adsorption-precipitation (Randazzo et al., 2020) and precipitation with $20 \%$ polyethylene-glycol (PEG) 6000 (Chavarria-Miró et al., 2020). Although Tanhaei et al. (2021) detected successfully SARS-CoV-2 from influent and effluent wastewater samples using an adsorptionelution technique, they used different eluent and PEG 6000 as secondary step viral precipitation which is different from our method. The absence of HCoV-NL63 in all raw sewage samples in our study; however, positive results of the SARSCoV-2 in some recent reports (Chavarria-Miró et al., 2020; Randazzo et al., 2020; Tanhaei et al., 2021) may also return to some mutations in the recent strain increased its ability to be excreted in the stool. This change in nature of respiratory viruses and the gained characters to be excreted in the stool may increase the importance of sewage to indicate the new viral strains and also the new characters according to the non-silent mutations for both enteric viruses and respiratory viruses.

The results also showed $5 \%, 2 \%, 3 \%, 0 \%, 0 \%, 2 \%$, and $0 \%$ as frequency percentages of adenovirus types 4 and 7 , parainfluenza virus types 1,2 , and 3 , and respiratory 
syncytial virus types A and B, respectively, in the clinical specimens. Our percentages of the prevalence of parainfluenza virus type 1,2, and 3 and respiratory syncytial virus types $\mathrm{A}$ and $\mathrm{B}$ in clinical specimens are less than the percentages of the prevalence of the same viruses in nasopharyngeal aspirates and cell culture supernatants reported by Dingle et al. (2004). On the other hand, our percentage of prevalence of adenovirus in the clinical specimens is less than the percentage of prevalence of the same virus in the nasopharyngeal swabs' specimens reported by Thounaojam et al. (2016), which types 2 and 4 of adenovirus were identified. At the same time, only adenovirus type 4 with a low percentage $(4.17 \%)$ was detected, while complete absence of all the other investigated respiratory viruses was observed in raw sewage samples. This may return to the low percentages of parainfluenza type 1, respiratory syncytial virus type A, and adenovirus type 7 in clinical specimens. Although raw sewage samples represented an excellent model to express the frequency of enteric viruses in different communities in addition to the most prevalent genotypes in these communities (El-Esnawy et al., 2010; El-Senousy et al., 2015, $2018,2020)$, noroviruses were not detected in raw sewage samples; however, they were detected in stool specimens in low percentage in the study of El-Senousy et al. (2014). In all the studies which showed similarity in the most prevalent genotypes in clinical specimens and raw sewage samples, high positivity percentages of different enteric viruses (rotavirus groups $\mathrm{A}$ and $\mathrm{C}$, Coxsackievirus B4, astroviruses genogroups $\mathrm{A}$ and $\mathrm{B}$ ) were observed in the clinical specimens (El-Esnawy et al., 2010; El-Senousy et al., 2014, 2015, 2018, 2020). In addition to the positivity percentages of viruses in clinical specimens which affect the number of viral particles (genome copies or infectious units) which contaminate the raw sewage, another important reason affects the viral load in the raw sewage which is the pathway of viruses from infected persons to raw sewage. A direct pathway is usually observed in the case of enteric viruses secreted in the stool of the infected persons; however, an indirect pathway is usually observed in case of respiratory viruses secreted in mouth, nose, and eyes secretions. This may be the reason for the higher percentage of enteric adenoviruses $(95.45 \%)$ than non-enteric adenoviruses $(4.55 \%)$ in raw sewage samples with a higher prevalence of adenovirus type 41 than adenovirus type 40 . This high frequency of adenovirus type 41 in raw sewage was supported by other reports (El-Senousy et al., 2013; Fong et al., 2010). Also, the predominance of human adenovirus $\mathrm{F}$ which includes adenovirus type 40 and adenovirus type 41 was reported in the raw sewage (Wieczorek et al., 2015). Some reports indicated the detection of respiratory viruses in sewage samples such as adenovirus types 2 and 3 (Fong et al., 2010), influenza viruses (Heijnen \& Medema, 2011), severe acute respiratory syndrome coronavirus 2 (SARS-CoV-2) (Chavarria-Miró et al., 2020;
Randazzo et al., 2020; Tanhaei et al., 2021); however, more studies are needed to show if sewage could be used as a good model to express the frequency percentages and the most prevalent genotypes of respiratory viruses in different communities.

\section{Conclusions}

The complete absence of HCoV-NL63 in Egyptian clinical specimens from children and raw sewage samples from November 2005 to January 2007 may lead us to re-survey the virus in the Egyptian community according to the periodicity of infection of the virus taking into consideration the suitable concentration methods for enveloped viruses. On the other hand, sewage may play an important role in the early warning and characterization of the viral new strains; however, if the viral load which contaminates the raw sewage is high and suitable and efficient methods of viral concentration are used.

Acknowledgements This research was supported by National Research Center in Cairo (Project Number W.N.0403, 2006-2009).

\section{References}

Arden, K. E., Nissen, M. D., Sloots, T. P., \& Mackay, I. M. (2005). New human coronavirus HCoV-NL63 associated with severe lower respiratory tract disease in Australia. Journal of Medical Virology, 75, 455-462.

Auburn, H., Zuckerman, M., Broughton, S., \& Greenough, A. (2011). Detection of nine respiratory RNA viruses using three multiplex RT-PCR assays incorporating a novel RNA internal control transcript. Journal of Virological Methods, 176(1-2), 9-13.

Bastien, N., Anderson, K., Hart, L., Van Caeseele, P., Brandt, K., Milley, D., Hatchette, T., III., Weiss, E. C., \& Li, Y. (2005). Human coronavirus NL63 infection in Canada. The Journal of Infectious Diseases, 191, 503-506.

Chavarria-Miró, G., Anfruns-Estrada, E., Guix, S., Paraira, M., Galofré, B., Sáanchez, G., Pintó, R., \& Bosch, A. (2020). Sentinel surveillance of SARS-CoV-2 in wastewater anticipates the occurrence of COVID-19 cases. medRxiv. https://doi.org/10.1101/2020. 06.13.20129627

Chiu, S. S., Chan, K. H., Chu, K. W., Kwan, S. W., Guan, Y., Poon, L. L., \& Peiris, J. S. M. (2005). Human coronavirus NL63 infection and other coronavirus infections in children hospitalized with acute respiratory disease in Hong Kong China. Clinical Infectious Diseases, 40, 1721-1729.

Dijkman, R., Jebbink, M. F., El Idrissi, N. B., Pyrc, K., Müller, M. A., Kuijpers, T. W., Zaaijer, H. L., \& Van Der Hoek, L. (2008). Human coronavirus NL63 and 229E seroconversion in children. Journal of Clinical Microbiology, 46, 2368-2373.

Dingle, K. E., Crook, D., \& Jeffery, K. (2004). Stable and noncompetitive RNA internal control for routine clinical diagnostic reverse transcription-PCR. Journal of Clinical Microbiology, 42(3), 1003-1011.

Drosten, C., Gunther, S., Preiser, W., Van Der Werf, S., Brodt, H. R., Becker, S., Rabenau, H., Panning, M., Kolesnikova, L., Fouchier, R. A., \& Berger, A. (2003). Identification of anovel coronavirus 
in patients with severe acute respiratory syndrome. New England Journal of Medicine, 348, 1967-1976.

El-Esnawy, N. A., El-Senousy, W. M., Hammad, I. A., Abada, E. A., Abu-Zekry, M., \& Rizk, N. M. (2010). Epidemiology of rotavirus in Greater Cairo. The New Egyptian Journal of Medicine, 42(1), 43-51.

El-Senousy, W. M., Barakat, A. B., Ghanem, H. E., \& Kamel, M. A. (2013). Molecular epidemiology of human adenoviruses and rotaviruses as candidate viral indicators in the Egyptian sewage and water samples. World Applied Sciences Journal, 27(10), 1235-1247.

El-Senousy, W. M., El-Gamal, M. S., Mousa, A. A. E., El-Hawary, S. E., \& Fathi, M. N. (2014). Prevalence of noroviruses among detected enteric viruses in Egyptian aquatic environment. World Applied Sciences Journal, 32(11), 2186-2205.

El-Senousy, W. M., Ragab, A. M. E., \& Handak, E. M. A. (2015). Prevalence of rotaviruses groups $\mathrm{A}$ and $\mathrm{C}$ in Egyptian children and aquatic environment. Food and Environmental Virology, 7(2), 132-141.

El-Senousy, W. M., Abdel-Moneim, A., Abdel-Latif, M., EL-Hefnawy, M. H., \& Khalil, R. G. (2018). Coxsackievirus B4 as a causative agent of diabetes mellitus type 1: Is there a role of inefficiently treated drinking water and sewage in virus spreading? Food and Environmental Virology, 10(1), 89-98.

El-Senousy, W. M., Abu Senna, A. S. M., Mohsen, N. A., Hasan, S. F., \& Sidkey, N. M. (2020). Clinical and environmental surveillance of rotavirus common genotypes showed high prevalence of common P genotypes in Egypt. Food and Environmental Virology, 12(2), 99-117.

Esper, F., Weibel, C., Ferguson, D., Landry, M. L., \& Kahn, J. S. (2005). Evidence of a novel human coronavirus that is associated with respiratory tract disease in infants and young children. Journal of Infectious Diseases, 191, 492-498.

Firquet, S. (2015). Survival of enveloped and non-enveloped viruses on inanimate surfaces. Microbes and Environments, 30, 140-144.

Fong, T. T., Phanikumar, M. S., Xagoraraki, I., \& Rose, J. B. (2010). Quantitative detection of human adenoviruses in wastewater and combined sewer overflows influencing a Michigan river. Applied and Environmental Microbiology, 76, 715-723.

Fouchier, R. A., Hartwig, N. G., Bestebroer, T. M., Niemeyer, B., de Jong, J. C., Simon, J. H., \& Osterhaus, A. D. (2004). A previously undescribed coronavirus associated with respiratory disease in humans. Proceedings of the National Academy of Sciences of the United States of America, 101, 6212-6216.

Hamre, D., \& Procknow, J. J. (1966). A new virus isolated from the human respiratory tract. Proceedings of the Society for Experimental Biology and Medicine, 121, 190-192.

Heijnen, L., \& Medema, G. (2011). Surveillance of Influenza A and the pandemic influenza A (H1N1) 2009 in sewage and surface water in the Netherlands. Journal of Water and Health, 9, 434-442.

Kaiser, L., Regamey, N., Roiha, H., Deffernez, C., \& Frey, U. (2005). Human coronavirus NL63 associated with lower respiratory tract symptoms in early life. The Pediatric Infectious Disease Journal, 24, 1015-1017.

Katzenelson, E., Fattal, B., \& Hostovesky, T. (1976). Organic flocculation: An efficient second-step concentration method for the detection of viruses in tap water. Applied and Environmental Microbiology, 32, 838-839.

Ksiazek, T. G., Erdman, D., Goldsmith, C. S., Zaki, S. R., Peret, T., Emery, S., Tong, S., Urbani, C., Comer, J. A., Lim, W., \& Rollin, P. E. (2003). A novel coronavirus associated with severe acute respiratory syndrome. New England Journal of Medicine, 348, 1953-1966.

McIntosh, K., Dees, J. H., Becker, W. B., Kapikian, A. Z., \& Chanock, R. M. (1967). Recovery in tracheal organ cultures of novel viruses from patients with respiratory disease. Proceedings of the
National Academy of Sciences of the United States of America, 57, 933-940.

Moes, E., Vijgen, L., Keyaerts, E., Zlateva, K., Li, S., Maes, P., Pyrc, K., Berkhout, B., van der Hoek, L., \& Van Ranst, M. (2005). A novel pancoronavirus RT-PCR assay: Frequent detection of human coronavirus NL63 in children hospitalized with respiratory tract infections in Belgium. BMC Infectious Diseases, 1, $5-6$.

Puig, M., Jofre, J., Lucena, F., Allard, A., Wadell, G., \& Girones, R. (1994). Detection of adenoviruses and enteroviruses in polluted waters by nested PCR amplification. Applied and Environment Microbiology, 60, 2963-2970.

Randazzo, W., Truchado, P., Cuevas-Ferrando, E., Simón, P., Allende, A., \& Sánchez, G. (2020). SARS-CoV-2 RNA in wastewater anticipated COVID-19 occurrence in a low prevalence area. Water Research, 181, 115942.

Rose, J. B., Singh, S. N., Gerba, C. P., \& Kelley, L. M. (1984). Comparison of microporousfilters for concentration of viruses from wastewater. Applied and Environmental Microbiology, 47, 989-992.

Shao, X., Guo, X., Esper, F., Weibel, C., \& Kahn, J. S. (2007). Seroepidemiology of group I human coronaviruses in children. Journal of Clinical Virology, 40, 207-213.

Smith, E. M., \& Gerba, C. P. (1982). Development of a method for detection of human rotavirus in water and sewage. Applied and Environmental Microbiology, 43, 1440-1450.

Suzuki, A., Okamoto, M., Ohmi, A., Watanabe, O., Miyabayashi, S., \& Nishimura, H. (2005). Detection of human coronavirus-NL63 in children in Japan. The Pediatric Infectious Disease Journal, $24,645-646$.

Talbot, H. K., Shepherd, B. E., Crowe, J. E., Griffin, M. R., Edwards, K. M., \& Podsiad, A. B. (2009). The pediatric burden of human coronaviruses evaluated for twenty years. The Pediatric Infectious Disease Journal, 28(8), 682-687.

Tanhaei, M., Mohebbi, S. R., Hosseini, S. M., Rafieepoor, M., Kazemian, S., Ghaemi, A., Shamloei, S., Mirjalali, H., Aghdaei, H. A., \& Zali, M. R. (2021). The first detection of SARSCoV-2 RNA in the wastewater of Tehran, Iran. Environmental Science and Pollution Research. https://doi.org/10.1007/ s11356-021-13393-9

Thounaojam, A. D., Balakrishnan, A., \& Mun, A. B. (2016). Detection and molecular typing of human adenoviruses associated with respiratory illnesses in Kerala. Japanese Journal of Infectious Diseases, 69, 500-504.

Tyrrell, D. A., \& Bynoe, M. L. (1965). Cultivation of a novel type of common-cold virus in organ cultures. British Medical Journal, $1,1467-1470$.

Vabret, A., Mourez, T., Dina, J., van der Hoek, L., Gouarin, S., Petitjean, J., Brouard, J., \& Freymuth, F. (2005). Human coronavirus NL63, France. Emerging Infectious Diseases, 11, 1225-1229.

van der Hoek, L. (2007). Human coronaviruses: What do they cause? Antiviral Therapy, 12, 651-658.

van der Hoek, L., Pyrc, K., Jebbink, M. F., Vermeulen-Oost, W., Berkhout, R. J., Wolthers, K. C., Wertheim-van Dillen, P. M., Kaandorp, J., Spaargaren, J., \& Berkhout, B. (2004). Identification of a new human coronavirus. Nature Medicine, 10, 368-373.

van Der Hoek, L., Sure, K., Ihorst, G., Stang, A., Pyrc, K., Jebbink, M. F., Petersen, G., Forster, J., Berkhout, B., \& Uberla, K. (2005). Croup is associated with the novel coronavirus NL63. PLoS Medicine, 2, 240-242.

van der Hoek, L., Ihorst, G., Sure, K., Vabret, A., Dijkman, R., de Vries, M., Forster, J., Berkhout, B., \& Uberla, K. (2010). Burden of disease due to human coronavirus NL63 infections and periodicity of infection. Journal of Clinical Virology, 48(2), 104-108.

Vasickova, P., Pavlik, I., Verani, M., \& Carducci, A. (2010). Issues concerning survival of viruses on surfaces. Food and Environmental Virology, 2, 24-34. 
Wieczorek, M., Krzystoszek, A., \& Witek, A. (2015). Species-specific identification of human adenoviruses in sewage. Polish Journal of Microbiology, 64(1), 23-28.

Woo, P. C., Lau, S. K., Chu, C. M., Chan, K. H., Tsoi, H. W., Huang, Y., Wong, B. H., Poon, R. W., Cai, J. J., Luk, W. K., \& Poon, L. L. (2005). Characterization and complete genome sequence of a novel coronavirus, coronavirus HKU1, from patients with pneumonia. Journal of Virology, 79, 884-895.

Wu, D., Tu, C., Xin, C., Xuan, H., Meng, Q., Liu, Y., Yu, Y., Guan, Y., Jiang, Y., Yin, X., Crameri, G., Wang, M., Li, C., Liu, S., Liao, M., Feng, L., Xiang, H., Sun, J., Chen, J., ... Kong, X. (2005). Civets are equally susceptible to experimental infection by two different severe acute respiratory syndrome coronavirus isolates. Journal of Virology, 79, 2620-2625.

Wu, P. S., Chang, L. Y., Berkhout, B., van der Hoek, L., Lu, C. Y., Kao, C. L., Lee, P. I., Shao, P. L., Lee, C. Y., Huang, F. Y., \& Huang, L.
M. (2008). Clinical manifestations of human coronavirus NL63 infection in children in Taiwan. European Journal of Pediatrics, $167,75-80$.

Ye, Y., Ellenberg, R. M., Graham, K. E., \& Wigginton, K. R. (2016). Survivability, partitioning, and recovery of enveloped viruses in untreated municipal wastewater. Environmental Science \& Technology, 50, 5077-5085.

Publisher's Note Springer Nature remains neutral with regard to jurisdictional claims in published maps and institutional affiliations. 